\title{
An Exploratory Examination of Student Usage and Perceptions of Technology-based Learning Tools in a Blended Learning Class
}

\author{
Robert C. Zelin II \\ Minnesota State University, Mankato, USA
}

\begin{abstract}
The purpose of this study was to examine the usage of technology-based learning tools (TLTs) in a blended learning/hybrid cost accounting class. The tools used were screen capture videos, an animated avatar video, electronic flashcards with related games, and an electronic sample quiz with detailed solutions. Data for nine TLTs and one set of PowerPoint slides was captured within a learning management system. It was found that student usage was highest for the PowerPoint slides, the vocabulary-related flash cards with related games and the electronic sample quiz. Usage was lowest for the animated avatar video. When anonymously surveyed, students felt that vocabulary-related flashcards and electronic sample quiz added more value to their learning experience as opposed to the other two technology-based learning tools.
\end{abstract}

\section{Introduction}

The college classroom has transformed itself from a room with chalkboards and overhead projectors to a room with a SmartBoard that is connected to various audio and visual devices. For many, a classroom with four walls may not even exist- the classroom may be virtual. That is, the interaction between student and teacher and student and class material may be conducted via a computer, laptop, tablet, or smartphone. Kuhlenschmidt et al. discusses the impact of technology on teaching. The authors state that: (1) technology has had a positive influence on teaching because students receive faster feedback, students have better collaborative learning experiences, students and faculty can be reached at any time, and learning can take place anywhere at any time (2) technology has had a negative influence on teaching because computers may act as a distractor in class, the use of computer-generated slides does not permit higher levels of learning, and instructors may use technology to distance themselves from students (3) technology has had no impact on learning- the brain is what controls learning not technology [7]. Two technology-based learning tools that may have a positive impact on learning are screen capture tools and animated lessons utilizing avatars.

\section{Screen Capture Tools}

Many educators use screen capture products such as Jing, Snagit, Camtasia and Captivate. Each of these tools allows the educator to record her or his actions on a computer and to save those actions as a video which can be stored on a server or personal computer. Screen capture tools can also incorporate the author's voice and/or callouts. Drumheller et al. cite several advantages of screen casts (the resulting product of a screen capture tool): they are helpful to students who miss class, they help to refresh the memories of students who do attend class, they help the educator avoid re-teaching the material, and they can be used as supplemental out-of-class material [3]. Yelinek et al. stress that screen casts must incorporate sound instructional theory as well as taking into consideration characteristics of the material and the learner [11]. Even though many screen capture tools must be purchased (i.e. Snagit, Camtasia and Captivate), there are quite a few on the market that are cost free. Griffis authored an article that discusses the advantages and disadvantages of various free screen capture tools [5]. 


\section{Animations with Avatars}

Avatars are simply animated characters. Many individuals and authors associate avatars with a virtual space or world [4], [8], [2]. However, in an educational milieu the avatar can simply be a 2 or 3 dimensional character in a setting. Examples of settings are classrooms, offices, restaurants, etc. Chen et al. discussed a type of avatar called an animated pedagogical agent. This type of avatar includes characteristics that are human in nature such as gestures and facial expressions. For one of their studies, the authors created two different avatars: empathic and non-empathic. The empathic avatar looked friendly and conveyed concern for the students. The non-empathic avatar did not express concern and did not look friendly. The authors found that students rated the empathic avatar higher on the questions of "Do you like the learning activities more when learning interactively with the agent?" and "Are you willing to learn with the agent again". (page 68) Additionally, the students who encountered the empathic avatar were more willing to read from an e-textbook and more willing to do exercises that related to the material [1]. Two products that incorporate the use of avatars and are available for educators are Xtranormal and Read The Words.

\section{Technology-based Learning Tools Used in the Study}

The purpose of this study is to determine the usage by students of three different technology-based learning tools: Jing (a screen capture system), Xtranormal (animated video with avatars) and StudyMate (a learning system with flashcards, games and quizzes). Each of the three products will be described below. This study is exploratory in nature so no specific hypotheses will be purported.

Jing [6] is a free online product developed by TechSmith that allows the user to develop a series of screenshots or screen capture videos up to five minutes in length. The product is free but the user is not able to edit the finished product within Jing. The final product can be stored online at screencast.com or can be stored on the user's computer and be uploaded to the user's Learning Management System.

Xtranormal [10] is an Internet-based program that allows users to create three dimensional animated movies. The program is Internet-based so the user does not have to download any software to her or his computer. The user is only asked to set up an account. Once the account is created, the user is given points to aid in the creation of an animation.
Usually the user is granted enough points to create one or two animations. If the user wishes to continue using the product she or he can purchase a monthly plan with unlimited points or can purchase points at various levels. Points can be used to purchase collections, scenes and actors. Once the collection, scene and actor(s) are purchased, the user can commence production of the animation. The user has several voices to choose from for each actor (the user may also insert her or his voice or the voice of others). In addition, the user can select gestures for the actors, camera angles and shot locations in the scene. Upon completion of the animation, the user may store the animation on her or his computer or on Xtranormal's site. The animation can then be easily uploaded to most learning management systems.

Studymate [9] is a learning system authoring tool that is used to create learning activities, games and individual-assessment activities. For any vocabulary term or fact, an electronic flash card can be created. In addition, the creator can produce pick a letter, fill in the blank, matching and crossword games. The creator can also produce sample multiple choice and true/false questions that can be played in the form of a game or can be used for self-assessment. Student access to StudyMate tools can be accomplished via computer, smartphone or tablet. StudyMate integrates with many Learning Management Systems.

\section{The Study}

The data for this study were collected from a Cost Accounting class at a medium-sized midwest university in the United States. The class was a hybrid/blended learning class were the students met face to face with the instructor approximately 60 percent of the time. Thirty-three students were enrolled in the class. Twenty-two students were males and 11 students were females. Fifteen students $(46 \%)$ were accounting majors, six (18\%) were finance majors, six (18\%) were management majors and six (18\%) were various other majors. The Learning Management System (LMS) used was Desire2Learn. Within the LMS a module entitled budgeting was created. Within the budgeting module, ten items were found: one set of PowerPoint slides, five screen capture videos, one animated avatar video, two sets of flashcards and related games and one set of sample multiple choice questions in the form of a quiz game. The screen capture videos illustrated how to create a production budget, cash collections budget, cash budget and a budgeted balance sheet. The animated avatar video showed two television news reporters talking about 
late breaking budget news. Various screens on the wall in the news room showed components of the budgeting process. The news camera panned around the room to show the various screens. With regard to the flashcards, one set was devoted to vocabulary terms and the other was devoted to budget formulas. Even though many games were available (i.e. crosswords, fill in the blank, etc.), most students reported that they either flipped over the electronic flashcards and/or played a matching game. Finally the multiple choice quiz game supplied the student with various multiple choice questions that were similar to those found on the end of chapter quiz. If the student selected a correct answer, "correct" would flash on the screen. If the student selected the wrong answer, a detailed solution to the question would appear. The LMS was used to collect usage and length of time data for every student for every component within the module.

Additional data about student perceptions of the technology-based learning tools was collected via an anonymous survey administered near the end of the semester. Students were offered five extra credit points to complete the survey (possible points for the course totaled 1000). Every student in the class participated in the optional survey. The survey not only asked questions about the instructor-generated screen capture video tutorials, avatar-related tutorials and the StudyMate activities but also asked questions about problems worked in class, an online homework management system, and hybrid/blended-learning classes in general.

\section{The Results}

Table 1 presents statistics about student usage of the various technology-based learning tools. Students viewed the PowerPoint slides with the greatest frequency (31 students out of 33), followed by vocabulary flash cards ( 29 students), which was followed by sample multiple choice questions with solutions (15 students). The lowest usage rates were found for the animation video produced with avatars (6 students) and a screencast video that introduced the cash budget ( 9 students). When average time spent per student with a learning tool was examined, the longest time, 59 minutes (m) 8 seconds (s), was devoted to the vocabulary flashcards which was followed by the PowerPoint slides on budgeting $(52 \mathrm{~m} 1 \mathrm{~s})$ and the sample multiple choice problems with solution $(48 \mathrm{~m} 46 \mathrm{~s})$. The lowest resulting usage times were for the avatar animation $(3 \mathrm{~m} 30 \mathrm{~s})$ and the cash budget screencast ( $3 \mathrm{~m} 44 \mathrm{~s})$.

It is not surprising that the sample PowerPoint slides, vocabulary flash cards and sample multiple choice questions were the three most popular items.
Many students do not read their textbook and rely primarily on the PowerPoint slides as their main source of information. In addition, the PowerPoint slides were used in class by the instructor. So if the student wished to follow along in class, she or he would have opened up the slides. The vocabulary flashcards probably were a popular item because the students completed a short quiz at the end of each chapter that involved matching various vocabulary terms to a related definition. Finally the sample multiple choice questions with solutions would have been of interest because the end of chapter quiz was mainly multiple choice questions. It is surprising that only 15 students ( $45 \%$ of the class) accessed this feature especially since the learning tool questions were very similar to those found on the end of chapter quiz. It was disappointing to the instructor that only six students ( $18 \%$ of the class) accessed the animation with avatars since the learning tool is time-intensive to create. The low usage rate may be due to student's not budgeting enough time to view all of the learning tools, the student not being aware of the learning tool or the student not valuing the learning tool. Further research should be conducted in order to try to determine the reason.

In Table 2 correlation coefficients can be found for the various technology-related learning tools. Two correlations were run. The first one was with the score on the end of chapter multiple choice quiz for budgeting and the second one was with total points earned in the class which was reported at the end of the semester. Based on the results reported above regarding Table 1, it could be hypothesized that the highest positive correlations should be reported for PowerPoint slides, vocabulary flash cards and sample multiple choice questions. The two highest correlations were reported for the PowerPoint slides and for the sample multiple choice questions. However, a negative correlation was reported for vocabulary flashcards. A possible explanation for this negative correlation might be that the vocabulary flashcard material related more to the vocabulary matching quiz given at the end of the chapter and not the end of chapter matching quiz. It was surprising that the avatar animation and some of the screen captures produced negative correlations. Further research needs to be conducted to see if a larger sample size will produce a different result.

Tables 3 and 4 illustrate the results of the anonymous student survey. Table 3 relates to the video screen capture tutorials that were prepared by the instructor. During the course of the semester the students were exposed to over 20 videos that the instructor produced. In this particular study data for only five $(25 \%)$ of the 20 videos was examined. The 
results from the survey are presented in terms of lowest recorded response, highest recorded response, mean value of all responses and standard deviation for all responses. For each survey statement, a seven point Likert-type scale was used where one represented "Strongly Disagree" and seven represented "Strongly Agree."

Table 4 summarizes the results of the student survey statements that related to animations with avatars. Students were exposed to four animations during the semester and only one (25\%) related to the budgeting chapter. The same Likert-type scale was utilized and the same statistics were calculated.

Table 5 shows the students' reactions to statements about the use of the StudyMate tools. Those tools included Vocabulary/Equation flashcards and related games (students primarily participated in the matching game) and sample multiple choice quiz questions with detailed solutions. As with the other two sections, the same Likert-type scale was used and the same statistics were presented.

Many of the statements in the screen capture video tutorials (see Table 3 ) and the statements in the animations using avatars tutorials (see Table 4) are of a similar nature so a comparison of the two technology-based learning tools is reasonable. The first question in each section dealt with whether the students found the tutorials to be interesting. Students reported that the instructor prepared video tutorials (mean score of 6.06) were more interesting than the avatar animations (mean score of 5.03). In fact, as Tables 3 and 4 illustrate, on every measure the means were higher for the instructor prepared screen capture tutorials versus the instructor prepared avatar animations (The tutorials helped me to understand chapter concepts: 6.303 versus 5.063; I enjoyed watching the tutorials: 5.788 versus 4.938 ; Watching the tutorial aided in improving my test performance: 5.906 versus 4.594; I would recommend the tutorials for future classes: 6.125 versus 4.938; I liked being able to watch the tutorials multiple times: 6.25 versus 4.935 (where $1=$ Strongly Disagree and $7=$ Strongly Agree)). When students were asked to react to the statement "I could have learned the same things from a lecture that I learned from the tutorial", the mean values indicated that both technology-based learning tools were slightly less preferred over a lecture (4.938 for instructor prepared video and 4.781 for the avatar animation).

Table 5 illustrates that the students seemed to approve of the StudyMate technology-based tools more than the videos discussed above. The survey results indicate a mean score of 6.788 for the StudyMate Vocabulary product with related games and 6.697 for the StudyMate Multiple Choice product with related games on the measure that the product helped the students to learn the material. Both of these mean scores were higher than those found for the other two technology-based learning tools. Mean scores were also higher on the recommendation for future classes measure (6.879 for vocabulary and 6.788 for multiple choice).

A final measure, quality of the tutorial or product, was used for all four technology-based learning tools. The Likert-type scale was modified so that $1=$ Very Poor Quality and 7=Excellent Quality. The mean quality ratings for the instructor created tutorials, the avatar animations, the StudyMate Vocabulary product and the StudyMate Multiple Choice product are 6.387, 5.5, 6.636, and 6.576 respectively. Once again the students exhibited a preference for the StudyMate tools.

It is interesting to note that for the particular chapter on budgeting that was examined only 9 students (27.3 percent) viewed the avatar animation, at most 12 students ( 36.4 percent) viewed one of the instructor prepared videos, 15 students ( 45.5 percent) viewed the StudyMate sample multiple choice questions and 29 students (87.9 percent) viewed the StudyMate Vocabulary flashcards. Thus, there is a possibility that for at least the budgeting chapter, the students may have evaluated material that they never examined.

\section{Limitations and Future Research}

This study has several limitations. First, it was only conducted at one university and in one class. Second, the number of participants, 33, was low. Third, the study only considered one module in the class. The study was exploratory in nature so in the future the author should increase the participant size and examine more modules.

\section{Conclusion}

Technology-based learning tools are becoming a staple in many academic settings. Today's students are often confronted with a plethora of learning tools. In this study, students chose technology-based learning tools that they perceived would help them the most on their end of chapter quizzes. A surprising finding was that students who were performing poorly in the class did not access other technology-based learning tools that may have aided them in understanding the material. Another interesting finding was that the students seemed to place more value on the easier to develop learning tools. 


\begin{tabular}{|c|c|c|c|c|c|c|c|c|}
\hline \multicolumn{9}{|c|}{ Table 1. Student Usage of Technology-based Learning Tools } \\
\hline Activity & $\begin{array}{l}\text { Students } \\
\text { Using }\end{array}$ & $\begin{array}{c}\text { Learning } \\
\text { Tool } \\
\text { Category }\end{array}$ & Length & $\begin{array}{c}\text { Average } \\
\text { time } \\
\text { spent }\end{array}$ & $\begin{array}{l}\text { Lowest } \\
\text { number } \\
\text { of visits }\end{array}$ & $\begin{array}{l}\text { Highest } \\
\text { number } \\
\text { of visits }\end{array}$ & $\begin{array}{c}\text { Shortest } \\
\text { time }\end{array}$ & $\begin{array}{c}\text { Longest } \\
\text { time }\end{array}$ \\
\hline $\begin{array}{l}\text { Budgeting } \\
\text { PowerPoint } \\
\text { Slides }\end{array}$ & 31 & PPT & & $52 \mathrm{~m} 1 \mathrm{~s}$ & 1 & 8 & $3 \mathrm{~s}$ & $2 \mathrm{~h} 41 \mathrm{~m} 30 \mathrm{~s}$ \\
\hline $\begin{array}{l}\text { How to } \\
\text { Prepare a } \\
\text { Production } \\
\text { Budget }\end{array}$ & 10 & $\mathrm{SC}$ & $3 \mathrm{~m} 41 \mathrm{~s}$ & $8 \mathrm{~m} 55 \mathrm{~s}$ & 1 & 4 & $15 \mathrm{~s}$ & $37 \mathrm{~m} 54 \mathrm{~s}$ \\
\hline $\begin{array}{l}\text { How to } \\
\text { Prepare a } \\
\text { Cash } \\
\text { Collections } \\
\text { Budget }\end{array}$ & 10 & $\mathrm{SC}$ & $3 \mathrm{~m} 14 \mathrm{~s}$ & $14 \mathrm{~m} 16 \mathrm{~s}$ & 1 & 4 & $15 \mathrm{~s}$ & $54 \mathrm{~m} 20 \mathrm{~s}$ \\
\hline $\begin{array}{l}\text { Introduction } \\
\text { to Cash } \\
\text { Budget }\end{array}$ & 9 & $\mathrm{SC}$ & $2 \mathrm{~m} 31 \mathrm{~s}$ & $5 \mathrm{~m} 28 \mathrm{~s}$ & 1 & 8 & $19 \mathrm{~s}$ & $22 \mathrm{~m} 3 \mathrm{~s}$ \\
\hline $\begin{array}{l}\text { Cash Budget } \\
\text { Example }\end{array}$ & 12 & $\mathrm{SC}$ & $2 \mathrm{~m}$ & $3 \mathrm{~m} 44 \mathrm{~s}$ & 1 & 14 & $4 \mathrm{~s}$ & $20 \mathrm{~m} 30 \mathrm{~s}$ \\
\hline $\begin{array}{l}\text { How to } \\
\text { Prepare a } \\
\text { Budgeted } \\
\text { Balance } \\
\text { Sheet }\end{array}$ & 10 & $\mathrm{SC}$ & $2 \mathrm{~m} 33 \mathrm{~s}$ & $5 \mathrm{~m} 27 \mathrm{~s}$ & 1 & 2 & $4 \mathrm{~s}$ & $28 \mathrm{~m} 26 \mathrm{~s}$ \\
\hline $\begin{array}{l}\text { Budgeting } \\
\text { with Avatars }\end{array}$ & 6 & AVA & $2 \mathrm{~m} 3 \mathrm{~s}$ & $3 \mathrm{~m} 30 \mathrm{~s}$ & 1 & 2 & $5 \mathrm{~s}$ & $16 \mathrm{~m} 21 \mathrm{~s}$ \\
\hline $\begin{array}{l}\text { Vocabulary } \\
\text { Flashcards }\end{array}$ & 29 & $\mathrm{FC}$ & & $59 \mathrm{~m} 8 \mathrm{~s}$ & 1 & 13 & $31 \mathrm{~s}$ & $3 \mathrm{~h} 43 \mathrm{~m} 59 \mathrm{~s}$ \\
\hline $\begin{array}{l}\text { Budget } \\
\text { Formula } \\
\text { Flashcards }\end{array}$ & 12 & $\mathrm{FC}$ & & $17 \mathrm{~m} 23 \mathrm{~s}$ & 1 & 4 & $25 \mathrm{~s}$ & $1 \mathrm{~h} 26 \mathrm{~m} 9 \mathrm{~s}$ \\
\hline $\begin{array}{l}\text { Sample } \\
\text { Multiple } \\
\text { Choice } \\
\text { Problems } \\
\text { with } \\
\text { Solutions }\end{array}$ & 15 & $\mathrm{MC}$ & & $48 \mathrm{~m} 46 \mathrm{~s}$ & 1 & 9 & $7 \mathrm{~s}$ & $3 \mathrm{~h} 39 \mathrm{~m} 11 \mathrm{~s}$ \\
\hline
\end{tabular}


Table 2. Correlation Coefficients for Various Learning Tools

\begin{tabular}{|l|c|r|}
\hline \multicolumn{3}{|c|}{ Table 2. Correlation Coefficients for Various Learning Tools } \\
\hline Activity & $\begin{array}{c}\text { Correlation Coefficient with End } \\
\text { of Chapter Quiz }\end{array}$ & $\begin{array}{c}\text { Correlation Coefficient with } \\
\text { Total Points in Class }\end{array}$ \\
\hline Budgeting PowerPoint Slides & 0.172137618 & 0.024104796 \\
\hline $\begin{array}{l}\text { How to Prepare a Production } \\
\text { Budget }\end{array}$ & -0.350445437 & -0.180371603 \\
\hline $\begin{array}{l}\text { How to Prepare a Cash } \\
\text { Collections Budget }\end{array}$ & -0.044957942 & -0.184459251 \\
\hline Introduction to Cash Budget & 0.103393188 & 0.0417208 \\
\hline Cash Budget Example & 0.006175583 & -0.180500761 \\
\hline Budgeted Balance Sheet & 0.044282818 & -0.1381048 \\
\hline Budgeting with Avatars & -0.30343136 & -0.0685721 \\
\hline Vocabulary Flashcards & -0.124413944 & -0.053023048 \\
\hline Budget Formula Flashcards & -0.016213654 & 0.242502723 \\
\hline $\begin{array}{l}\text { Sample Multiple Choice } \\
\text { Problems with Solutions }\end{array}$ & 0.126815616 & 0.279613316 \\
\hline
\end{tabular}

\begin{tabular}{|c|c|c|c|c|}
\hline \multicolumn{5}{|c|}{$\begin{array}{c}\text { Table 3. Results from Anonymous Student Survey for Screen Capture Video Tutorials } \\
\text { Prepared by the Instructor }\end{array}$} \\
\hline Statement on Survey & Minimum & Maximum & Mean & $\begin{array}{l}\text { Standard } \\
\text { Deviation }\end{array}$ \\
\hline The tutorials were interesting & 4 & 7 & 6.060606 & 0.863836 \\
\hline $\begin{array}{l}\text { The tutorial's length was } \\
\text { reasonable }\end{array}$ & 5 & 7 & 6.606061 & 0.609272 \\
\hline $\begin{array}{l}\text { The tutorials helped me to } \\
\text { understand chapter concepts }\end{array}$ & 4 & 7 & 6.30303 & 0.809508 \\
\hline I enjoyed watching the tutorials & 3 & 7 & 5.787879 & 1.139012 \\
\hline $\begin{array}{l}\text { Watching the tutorial aided in } \\
\text { improving my test performance }\end{array}$ & 4 & 7 & 5.90625 & 0.995453 \\
\hline $\begin{array}{l}\text { I would recommend the tutorials } \\
\text { for future classes }\end{array}$ & 3 & 7 & 6.125 & 1.008032 \\
\hline $\begin{array}{l}\text { I could have learned the same } \\
\text { things from a lecture that I } \\
\text { learned from the tutorial }\end{array}$ & 2 & 7 & 4.9375 & 1.366358 \\
\hline $\begin{array}{l}\text { I liked being able to watch the } \\
\text { tutorials multiple times }\end{array}$ & 4 & 7 & 6.25 & 0.983739 \\
\hline $\begin{array}{l}\text { Rate the quality of the tutorials } \\
\text { (1= Very Poor, } 7=\text { Excellent) }\end{array}$ & 5 & 7 & 6.387097 & 0.558416 \\
\hline
\end{tabular}




\begin{tabular}{|c|c|c|c|c|}
\hline \multicolumn{5}{|c|}{$\begin{array}{c}\text { Table 4. Results from Anonymous Student Survey for Instructor-prepared Video Tutorials } \\
\text { with Avatar Animations }\end{array}$} \\
\hline Statement on Survey & Minimum & Maximum & Mean & $\begin{array}{l}\text { Standard } \\
\text { Deviation }\end{array}$ \\
\hline The tutorials were interesting & 1 & 7 & 5.03125 & 1.694096 \\
\hline $\begin{array}{l}\text { The tutorial's length was } \\
\text { reasonable }\end{array}$ & 1 & 7 & 5.625 & 1.3137 \\
\hline $\begin{array}{l}\text { The tutorials helped me to } \\
\text { understand chapter concepts }\end{array}$ & 1 & 7 & 5.0625 & 1.68365 \\
\hline I enjoyed watching the tutorials & 1 & 7 & 4.9375 & 1.564475 \\
\hline $\begin{array}{l}\text { Watching the tutorial aided in } \\
\text { improving my test performance }\end{array}$ & 1 & 7 & 4.59375 & 1.720078 \\
\hline $\begin{array}{l}\text { I would recommend the tutorials } \\
\text { for future classes }\end{array}$ & 1 & 7 & 4.9375 & 1.702702 \\
\hline $\begin{array}{l}\text { I could have learned the same } \\
\text { things from a lecture that I } \\
\text { learned from the tutorial }\end{array}$ & 1 & 7 & 4.78125 & 1.58082 \\
\hline $\begin{array}{l}\text { I liked being able to watch the } \\
\text { tutorials multiple times }\end{array}$ & 1 & 7 & 4.935484 & 1.93107 \\
\hline $\begin{array}{l}\text { Should tutorials be created for } \\
\text { each chapter? }\end{array}$ & 1 & 7 & 4.40625 & 1.682153 \\
\hline $\begin{array}{l}\text { Rate the quality of the tutorials } \\
(1=\text { Very Poor, } 7=\text { Excellent })\end{array}$ & 3 & 7 & 5.5 & 1.270001 \\
\hline Unless otherwise noted, a & $\begin{array}{r}\text { Likert-tyl } \\
7=\text { Stro }\end{array}$ & $\begin{array}{l}\text { was used } \\
\text { ree }\end{array}$ & ngly Disa & and \\
\hline
\end{tabular}


Table 5. Results from Anonymous Student Survey for StudyMate Vocabulary Flashcards and Multiple Choice Quizzes with Related Games

\begin{tabular}{|c|c|c|c|c|}
\hline Statement on Survey & Minimum & Maximum & Mean & $\begin{array}{c}\text { Standard } \\
\text { Deviation }\end{array}$ \\
\hline \multicolumn{5}{|l|}{$\begin{array}{l}\text { StudyMate Vocabulary Product } \\
\text { with games }\end{array}$} \\
\hline $\begin{array}{l}\text { The product helped me to learn } \\
\text { key terms }\end{array}$ & 5 & 7 & 6.787879 & 0.545297 \\
\hline $\begin{array}{l}\text { I liked being able to view the } \\
\text { product multiple times }\end{array}$ & 4 & 7 & 6.363636 & 0.92932 \\
\hline $\begin{array}{l}\text { I would recommend the product } \\
\text { for future classes }\end{array}$ & 4 & 7 & 6.878788 & 0.545297 \\
\hline $\begin{array}{l}\text { Rate the quality of the product } \\
\text { (1=Very Poor, } 7=\text { Excellent })\end{array}$ & 3 & 7 & 6.636364 & 0.822275 \\
\hline \multicolumn{5}{|l|}{$\begin{array}{l}\text { StudyMate Multiple Choice } \\
\text { Product with games and detailed } \\
\text { solutions }\end{array}$} \\
\hline $\begin{array}{l}\text { The product helped me to learn } \\
\text { concepts related to the chapters }\end{array}$ & 3 & 7 & 6.69697 & 0.883348 \\
\hline $\begin{array}{l}\text { I liked being able to view the } \\
\text { quiz questions multiple times }\end{array}$ & 3 & 7 & 6.575758 & 1.031695 \\
\hline $\begin{array}{l}\text { I would recommend the product } \\
\text { for future classes }\end{array}$ & 4 & 7 & 6.787879 & 0.649883 \\
\hline $\begin{array}{l}\text { Rate the quality of the product } \\
\text { (1= Very Poor, } 7=\text { Excellent) }\end{array}$ & 4 & 7 & 6.575758 & 0.830298 \\
\hline
\end{tabular}

Unless otherwise noted, a 7 point Likert-type scale was used with 1=Strongly Disagree and $7=$ Strongly Agree

\section{References}

[1] Chen, G.-D.et al., 2012. An Empathic Avatar in a Computer-Aided Learning Program to Encourage and Persuade Learners. Educational Technology \& Society, Volume 2, pp. 62-72.

[2] Deucher, S. \& Nodder, C., 2003. The impact of avatars and 3D virtual world creation on learning. Proceeding of the 16th Annual NACCQ Conference.

[3] Drumheller, K. \& Lawler, G., 2011. Capture Their Attention: Capturing Lessons Using Screen Capture Software. College Teaching, Volume 59, p. 59.

[4] Falloon, G., 2010. Using Avatars and Virtual Environments in Learning: What Do They Have to Offer?. British Journal of Educational Technology, Volume 41, pp. 108122.

[5] Griffis, P., 2009. Building Pathfinders with Free Screen Capture Tools. Informationn Technology and Libraries, pp. 189-190.
[6] Jing, n.d. Techsmith. [Online] Available at: http://www.techsmith.com/jing.html [Accessed May 2013].

[7] Kuhlenschmidt, S. \& Kacer, B., 2010. The Promise of Technology for College Instruction: From Drill and Practice to Avatars. New Directions for Teaching and Learning, Fall.pp. 23-31.

[8] Peterson, M., 2005. Learning interaction in an avatar-based virtual environment: a preliminary study.. PacCALL Journal, pp. 2940.

[9] Respondus, n.d. Studymate. [Online] Available at: http://www.respondus.com/products/studymate/ index.shtml

[Accessed May 2013].

[10] Xtranormal, n.d. Xtranormal. [Online] Available at: http://www.xtranormal.com/ [Accessed May 2013]. 
International Journal for e-Learning Security (IJeLS), Volume 3, Issue 1, March 2013

[11] Yelinek, K., Tarnowski, L., Hannon, P. \& Oliver, S., 2008. Captivate MenuBuilder: Creating an Online Tutorial for Teaching Software. The Clearning House, November/December.pp. 101-106. 